\title{
IJCIT
}

(Indonesian Journal on Computer and Information Technology) Journal Homepage: http://ejournal.bsi.ac.id/ejurnal/index.php/ijcit

\section{Analisis Persepsi Kemanfaatan dan Persepsi Kemudahan Penggunaan Terhadap Penggunaan Sistem Informasi Akademik}

\author{
Miftah Rakhmadian ${ }^{1}$, Putri Vina Sefaverdiana ${ }^{2}$, Nur Rahman ${ }^{3}$ \\ Pendidikan Ekonomi, IKIP Budi Utomo \\ Malang, Indonesia \\ e-mail: miftahrdian@gmail.com ${ }^{1}$, viseverputri@gmail.com ${ }^{2}$, nur.rahman66@gmail.com ${ }^{3}$
}

\begin{abstract}
A B S T R A K
Penelitian ini bertujuan untuk mengetahui bagaimana pengaruh persepsi kemanfaatan dan persepsi kemudahan penggunaan bagi mahasiswa terhadap niat untuk menggunakan sistem informasi akademik di IKIP Budi Utomo Malang baik secara parsial maupun secara simultan, kemudian mencari diantara faktor persepsi kemanfaatan dan persepsi kemudahan penggunaan manakah faktor yang paling dominan. Teknik analisis data yang digunakan dalam penelitian ini menggunakan analisis regresi berganda, uji t untuk mengetahui pengaruh antar variable secara parsial, dan uji $\mathrm{F}$ untuk mengetahui pengaruh antar variabel secara simultan. Hasil penelitian ini menunjukan bahwa variabel persepsi kemudahan penggunaan tidak berpengaruh secara parsial terhadap variabel niat untuk menggunakan. Hasil lain menunjukan bahwa variabel persepsi kemanfaatan berpengaruh secara parsial terhadap sikap terhadap penggunaan. persepsi kemanfaatan dan Persepsi kemudahan penggunaan dan secara simultan memberi pengaruh kepada niat untuk menggunakan sistem informasi akademik untuk mahasiswa dengan kontribusi sebesar $36 \%$. Persepsi kemanfaatan memberi pengaruh lebih dominan dibanding persepsi kemudahan penggunaan terhadap niat untuk menggunakan sistem informasi akademik untuk mahasiswa di IKIP Budi Utomo Malang.

Katakunci: Persepsi kemanfaatan, Persepsi kemudahan penggunaan, Niat untuk menggunakan, Sistem Informasi Akademik
\end{abstract}

\begin{abstract}
A B S TRACTS
This study aims to determine how the influence of perceived usefulness and perceived ease of use for students on the intention to use academic information systems at IKIP Budi Utomo Malang partially or simultaneously, then look for the perceptions of usefulness and perceived ease of use which are the most dominant factors. Data analysis techniques used in this study used multiple regression analysis, $t$ test to determine the effect of partial variables, and $F$ test to determine the effect of variables simultaneously. The results of this study indicate that the variable perceived ease of use has no partial effect on the intention variable to use. Other results show that the variable perceived usefulness partially influences attitudes toward use. perceived usefulness and perceived ease of use and simultaneously influence the intention to use academic information systems for students with a contribution of $36 \%$. The perception of usefulness gives more dominant influence than perceived ease of use of the intention to use academic information systems for students at IKIP Budi Utomo Malang. Keywords: Perceived Usefulness, Perceived Ease of Use, Intention to Use, Academic Information Systems.
\end{abstract}




\section{PENDAHULUAN}

Teknologi informasi salah satu bagian dari kebutuhan akan perkembangan zaman yang membantu para penggunanya menjadi lebih mudah serta efisien dalam pemanfaatannya (Fatmasari \& Ariandi, 2014).

Sistem Informasi adalah kumpulan elemen yang saling berhubungan satu sama lain untuk membentuk suatu kesatuan untuk mengintegrasi data, memproses dan menyimpan serta mendistribusikan informasi tersebut (Sutedjo \& Oetomo, 2006). Sistem informasi merupakan salah satu solusi dari permasalahan yang dihadapi organisasi, dan berguna untuk menghadapi tantangan di masa sekarang. Komponen sistem informasi terdiri dari: orang-orang (people), hardware, software, data, dan jaringan komunikasi (networks). Sementara informasi dikatakan berkualitas jika memperhatikan aspek relevansi, akurasi, dan tepat waktu (Fatmawati, 2015). Salah satu indikator suksesnya suatu sistem informasi menurut DeLone dan McLean adalah ketika sistem informasi tersebut diterima atau digunakan oleh penggunanya.

Salah satu model yang dapat menerangkan tentang bagaimana pengguna (user) mengerti dan mengaplikasikan suatu teknologi informasi adalah dengan menggunakan model TAM (Technology Acceptance Model). Secara teoritis dan praktis TAM merupakan model yang dianggap paling tepat dalam menjelaskan bagaimana user menerima sebuah sistem (Supriyanti \& Cholil, 2016). TAM pertama kali diperkenalkan oleh Davis pada tahun 1989, TAM adalah sebuah teori sistem informasi yang didesain guna menerangkan bagaimana pengguna mengerti dan mengaplikasikan sebuah teknologi informasi. Menurut Davis (1989) menyatakan bahwa TAM bertujuan untuk menjelaskan penerimaan teknologi oleh pengguna dengan mengarahkan dirinya pada persepsi pengguna (Gokcearslan, 2017). TAM menjelaskan dan memprediksikan penerimaan pemakai terhadap suatu teknologi berdasarkan dampak dari dua faktor, yaitu persepsi kemanfaatan (perceived usefulness) dan persepsi kemudahan penggunaan (perceived ease of use). Technology Acceptance Model (TAM) yang dikembangkan oleh Davis (1989) telah bekerja di berbagai bidang untuk menyelidiki penerimaan teknologi(Doleck, T., Bazelais, P., \& Lemay, 2017).
Perceived usefulness atau kegunaan yang dirasakan Menurut Davis (1989) didefinisikan sebagai sejauh mana seseorang berpikir bahwa menggunakan sistem tertentu akan meningkatkan kinerjanya. Perceived ease of use atau kemudahan yang dirasakan Menurut Davis (1989) didefinisikan sebagai tingkatan seseorang berpikir bahwa dengan menggunakan sistem tertentu akan terbebas dari usaha (Hamari, J., Keronen, 2017). Behavioral intention atau niat perilaku Menurut Davis (1989) didefinisikan sebagai sejauh mana seseorang telah merumuskan rencana sadar untuk melakukan atau tidak melakukan beberapa perilaku tertentu di masa yang akan datang (Maruping, L. M., Bala, H., Venkatesh, V., \& Brown, 2017).

IKIP Budi Utomo adalah salah satu perguruan tinggi swasta yang berada di Malang telah mengaplikasikan sistem informasi akademik untuk mengatur kegiatan perkuliahan mahasiswa. Mahasiswa sebagai salah satu pengguna sistem diwajibkan menggunakan SIAKAD dalam mengambil KRS, melihat jadwal kuliah, melihat nilai, dan kegiatan akademik lainnya. belum adanya penelitian mengenai persepsi kemanfaatan (perceived usefulness) dan persepsi kemudahan penggunaan (perceived ease of use) terhadap sikap mahasiswa dalam menggunakan sistem (Intention to Use), sehingga peneliti merasa perlu untuk meneliti hal tersebut untuk mengetahui apakah sistem diterima atau tidak oleh penggunanya.

Penelitian ini bertujuan untuk mengetahui bagaimana pengaruh persepsi kemanfaatan (perceived usefulness) dan persepsi kemudahan penggunaan (perceived ease of use) secara parsial maupun secara simultan terhadap sikap mahasiswa dalam pemakaian (intention to use) sistem informasi akademik (SIAKAD) di IKIP Budi Utomo Malang, kemudian mencari manakah diantara kedua faktor tersebut yang paling dominan pengaruhnya.

Penelitian sebelumnya menyatakan bahwa penerimaan SIPKD di instansi pemerintah di wilayah Yogyakarta dipengaruhi oleh persepsi pemakai terhadap kemudahan penggunaan sistem. Penerimaan SIPKD di instansi pemerintah di wilayah Yogyakarta tidak dipengaruhi oleh persepsi kemanfaatan sistem. Secara simultan persepsi kemudahan penggunaan dan persepsi kemanfaatan mempengaruhi penerimaan SIPKD (Sayekti \& Putarta, 2016). 
Hasil penelitian lain menunjukkan bahwa kemudahan penggunaan berpengaruh positif terhadap persepsi manfaat, dan sikap penggunaan. Hal tersebut menunjukkan bahwa apabila pengguna e-learning merasa bahwa sistem tersebut mudah digunakan maka akan memberikan manfaat bagi mahasiswa dan mempengaruhi penerimaan terhadap e-learning tersebut (Rahayu, Budiyanto, \& Palyama, 2017).

(1). Perceived ease of use (EOU) dari penggunaan ES-AHASS 02300 mendukung adanya suatu pengaruh yang positif dan signifikan terhadap perceived usefulness (U). (2). Perceived usefulness (U) secara parsial menunjukkan hasil yang berpengaruh positif dan signifikan terhadap behavioral intention (BI) untuk menggunakan ES-AHASS 02300. (3). Perceived ease of use (EOU) secara parsial menunjukkan terdapat pengaruh positif yang signifikan terhadap behavioral intention (BI) untuk menggunakan ES-AHASS 02300. (4). Diantara dua Faktor keyakinan pengguna yaitu perceived usefulness (U) dan perceived ease of use (EOU) secara simultan berpengaruh positif yang signifikan terhadap behavioral intention (BI) untuk menggunakan ES-AHASS 02300 (Wiguna, 2018).

Hipotesis yang diajukan dalam penelitian ini adalah sebagai berikut:

H1 Persepsi kemanfaatan secara parsial memberi pengaruh terhadap niat untuk menggunakan sistem.

H2 Persepsi kemudahan penggunaan secara parsial memberi pengaruh terhadap niat untuk menggunakan sistem.

H3 Persepsi kemanfaatan dan persepsi kemudahan penggunaan secara simultan memberi pengaruh terhadap niat untuk menggunakan sistem.

H4 Persepsi kemanfaatan memberi pengaruh dominan terhadap niat untuk menggunakan sistem.

\section{METODE PENELITIAN}

Metode penelitian yang digunakan dalam penelitian ini adalah menggunakan metode penelitian kuantitatif. Lokasi penelitian bertempat di IKIP Budi Utomo Malang, dimana sistem informasi akademik (SIAKAD) dijalankan. Objek pada penelitian ini adalah mahasiswa jurusan Pendidikan Ekonomi angkatan 2018, dimana mahasiswa-mahasiswa tersebut baru pertama kali menggunakan sistem informasi akademik (SIAKAD). Dari 63 kuesioner yang disebar, telah kembali 40 kuesioner yang kemudian diolah sebagai daftar penelitian.

Adapun skema penelitian yang diusulkan adalah sebagai berikut:

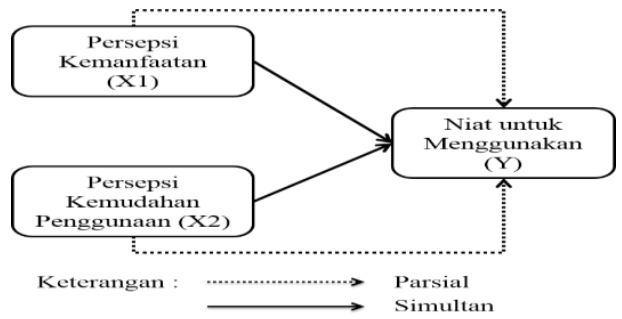

Gambar 1. Skema Penelitian

Rincian variabel dan indikator yang diteliti tampak pada Tabel 1.

Tabel 1. Variabel dan Indikator Penelitian

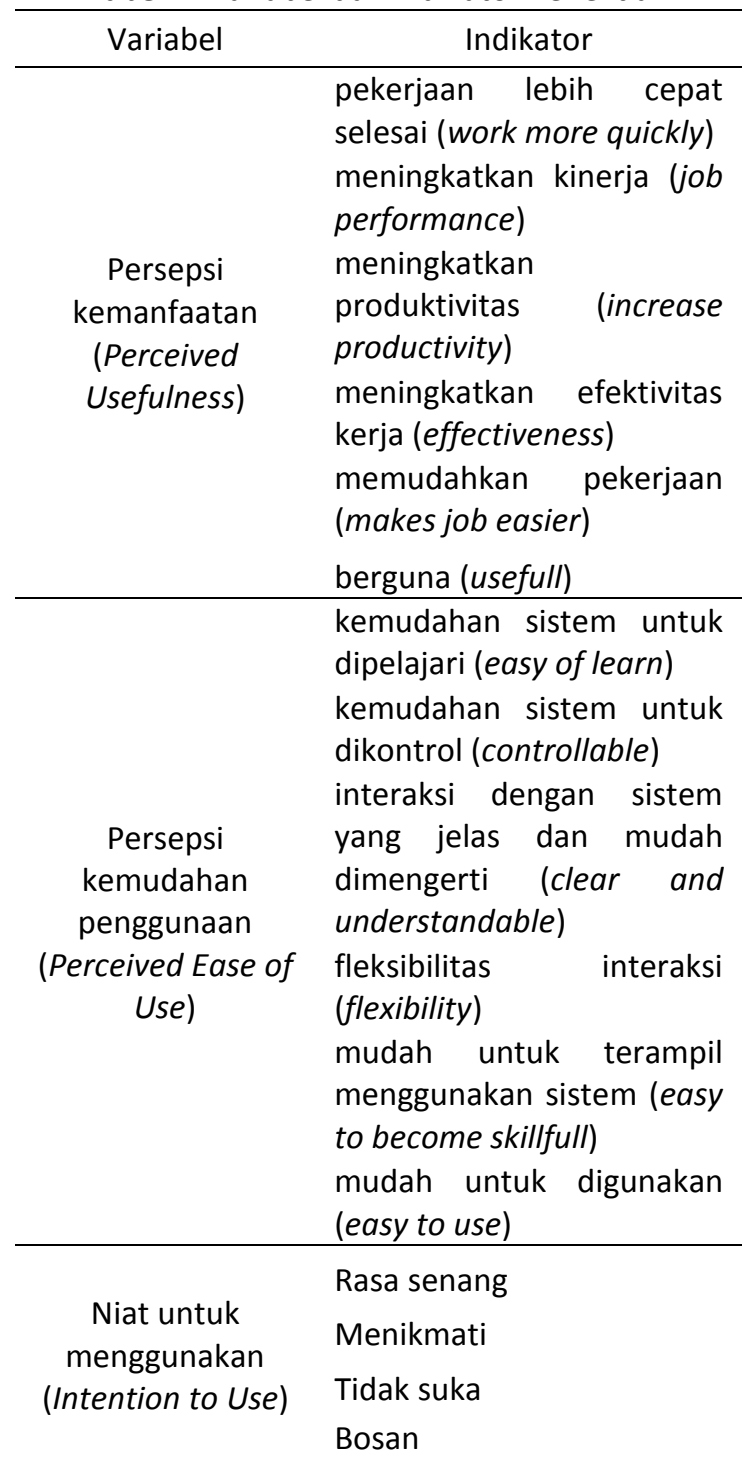


Kuesioner disebar sebelumnya dilakukan uji validitas dan reliabilitas untuk mengukur kelayakan dari isi kuesioner.

Teknik analisis data yang digunakan dalam penelitian ini menggunakan uji $t$, dan uji $F$ untuk mengetahui pengaruh antar variabel secara parsial maupun secara simultan, dan dilakukan analisis regresi berganda untuk mengetahui koefisien determinasinya. Sebelum data diolah dilakukan uji asumsi klasik untuk memastikan bahwa model telah memenuhi kriteria BLUE (Best Linear Unbiased Estimator).

\section{HASIL DAN PEMBAHASAN}

Data dalam penelitian ini dikumpulkan dengan menggunakan instrumen berupa kuesioner, jumlah keseluruhan kuesioner yang disebar sebanyak 63 kuesioner, dan kembali sebanyak 40 kuesioner untuk diolah sebagai data penelitian.

\subsection{Uji Validitas}

Tabel 2. Hasil Uji Validitas Instrumen

\begin{tabular}{|c|c|c|c|}
\hline $\begin{array}{c}\text { Item } \\
\text { Pertanyaan }\end{array}$ & $\begin{array}{c}r \\
\text { hitung }\end{array}$ & r tabel & $\begin{array}{c}\text { keterang } \\
\text { an }\end{array}$ \\
\hline Pertanyaan 1 & 0,4421 & 0,3120 & valid \\
\hline Pertanyaan 2 & 0,5659 & 0,3120 & valid \\
\hline Pertanyaan 3 & 0,5514 & 0,3120 & valid \\
\hline Pertanyaan 4 & 0,5061 & 0,3120 & valid \\
\hline Pertanyaan 5 & 0,5287 & 0,3120 & valid \\
\hline Pertanyaan 6 & 0,6952 & 0,3120 & valid \\
\hline Pertanyaan 7 & 0,6770 & 0,3120 & valid \\
\hline Pertanyaan 8 & 0,7878 & 0,3120 & valid \\
\hline Pertanyaan 9 & 0,6863 & 0,3120 & valid \\
\hline Pertanyaan 10 & 0,6864 & 0,3120 & valid \\
\hline Pertanyaan 11 & 0,7553 & 0,3120 & valid \\
\hline Pertanyaan 12 & 0,6596 & 0,3120 & valid \\
\hline Pertanyaan 13 & 0,7420 & 0,3120 & valid \\
\hline Pertanyaan 14 & 0,7550 & 0,3120 & valid \\
\hline Pertanyaan 15 & 0,7853 & 0,3120 & valid \\
\hline Pertanyaan 16 & 0,7683 & 0,3120 & valid \\
\hline Pertanyaan 17 & 0,5368 & 0,3120 & valid \\
\hline Pertanyaan 18 & 0,5092 & 0,3120 & valid \\
\hline
\end{tabular}

Hasil uji validitas untuk variabel persepsi kemanfaatan (perceived usefulness), persepsi kemudahan penggunaan (perceived ease of use), dan niat untuk menggunakan (intention to use) menunjukan bahwa semua item pernyataan berkorelasi dengan skor total pernyataan, sehingga tidak ada data yang harus dikeluarkan dari data analisis, semua data layak untuk masuk pada tahap analisis selanjutnya.

\subsection{Uji Reliabilitas}

Hasil uji reliabilitas instrumen dapat dilihat pada tabel berikut:

Tabel 3. Hasil Uji Reliabilitas

\begin{tabular}{cc}
\hline Cronbach's Alpha & N of Items \\
\hline .897 & 20 \\
\hline
\end{tabular}

Hasil perhitungan menunjukan nilai dari Cronbach's Alpha 0,897 lebih besar dari 0,80 yang berarti bahwa instrumen memiliki reliabilitas yang baik.

\subsection{Uji Asumsi Klasik}

3.3.1. Normalitas Data

Tabel 4. Hasil Uji Normalitas Data

One-Sample Kolmogorov-Smirnov Test

\begin{tabular}{llr}
\hline & & $\begin{array}{c}\text { Unstandardized } \\
\text { Residual }\end{array}$ \\
\hline $\mathrm{N}$ & Mean & 40 \\
Normal & Std. Deviation & .0000000 \\
Parameters & & 2.76759141 \\
Most Extreme & Absolute & .172 \\
Differences & Positive & .151 \\
& Negative & -.172 \\
Kolmogorov-Smirnov Z & 1.089 \\
Asymp. Sig. (2-tailed) & .187 \\
\hline
\end{tabular}

a. Test distribution is Normal.

Hasil uji normalitas data di atas menunjukan bahwa nilai signifikansi sebesar 0,187, nilai tersebut lebih besar dari 0,05, sehingga dapat disimpulkan bahwa data dalam penelitian ini berdistribusi normal. 


\subsubsection{Multikolinieritas Data}

Tabel 5. Hasil Uji Multikolinieritas Data Coefficients $^{\mathrm{a}}$

\begin{tabular}{|c|c|c|c|c|c|c|c|c|}
\hline \multirow[t]{2}{*}{ Model } & \multicolumn{2}{|c|}{$\begin{array}{l}\text { Unstandardized } \\
\text { Coefficients }\end{array}$} & \multirow{2}{*}{\multicolumn{2}{|c|}{$\begin{array}{c}\text { Standardized } \\
\text { Coefficients } \\
\text { Beta }\end{array}$}} & \multirow[t]{2}{*}{$\mathrm{t}$} & \multirow[t]{2}{*}{ Sig } & \multicolumn{2}{|c|}{$\begin{array}{l}\text { Collinearity } \\
\text { Statistics }\end{array}$} \\
\hline & B & Std. Error & & & & & Tolerance & VIF \\
\hline (Constant) & -2.611 & 4.398 & & & -.594 & .556 & & \\
\hline $1 \begin{array}{l}\text { Persepsi } \\
\text { penggunaan }\end{array}$ & .063 & .189 & & .061 & .334 & .740 & .527 & 1.897 \\
\hline Persepsi kemanfaatan & .488 & .160 & & .553 & 3.044 & .004 & .527 & 1.897 \\
\hline
\end{tabular}

a. Dependent Variabel: Niat untuk menggunakan Hasil uji Multikolinieritas menunjukan nilai VIF untuk variabel kualitas sistem sebesar 1,897 dan untuk variabel kualitas informasi sebesar 1,897 , keduanya memiliki nilai yang lebih kecil dari 10, sehingga dapat disimpulkan bahwa dalam model regresi tidak terjadi multikolinieritas.

\subsubsection{Autokorelasi}

Tabel 6. Hasil Uji Autokorelasi Data

Model Summary $^{\mathrm{b}}$
Error of

$R$ Adjusted the DurbinModel $R$ Square R Square Estimate Watson

\begin{tabular}{llllrr}
\hline 1 & $.597^{\mathrm{a}}$ & .356 & .321 & 2.841 & 1.613 \\
\hline a. & $\begin{array}{l}\text { Predictors: } \\
\text { kemanfaatan, } \\
\text { penggunaan. }\end{array}$ & $\begin{array}{c}\text { (Constant) } \\
\text { Persepsi }\end{array}$ & & $\begin{array}{r}\text { Persepsi } \\
\text { kemudahan }\end{array}$ \\
& & & &
\end{tabular}

b. Dependent Variabel: Niat untuk menggunakan

Hasil uji autokorelasi menunjukan nilai Durbin-Watson sebesar 1,613, nilai tersebut berada diantara -2 dan +2 , sehingga dapat disimpulkan bahwa dalam model penelitian tidak terdapat autokorelasi

\subsubsection{Heteroskedastisitas}

Pada gambar 2 dapat dilihat persebaran titik tidak membentuk satu pola tertentu.

Hasil serangkaian uji asumsi klasik menunjukan bahwa data memenuhi kriteria BLUE (Best Linear Unbiased Estimator).

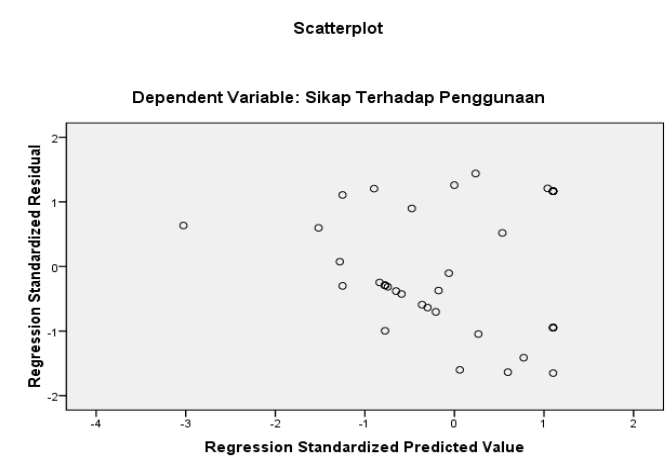

Gambar 2. Hasil Uji Heteroskedastisitas

\subsection{Uji Hipotesis}

Hasil perhitungan menggunakan analisis regresi berganda dapat dilihat pada tabel berikut:

Tabel 7. Hasil Analisis Regresi Berganda

\begin{tabular}{|c|c|c|c|c|c|}
\hline & $\begin{array}{c}\text { Koefi } \\
\text { sien } \\
\text { Regre } \\
\text { si }\end{array}$ & $\begin{array}{c}\mathrm{T} \\
\text { Hitu } \\
\mathrm{ng}\end{array}$ & Sig. & VIF & $\begin{array}{c}\text { Ket } \\
\text { era } \\
\text { nga } \\
\text { n }\end{array}$ \\
\hline Konstanta & $\begin{array}{c}- \\
0,654\end{array}$ & & & & \\
\hline $\begin{array}{l}\text { Persepsi } \\
\text { kemudahan } \\
\text { penggunaan } \\
\text { (X2) }\end{array}$ & 0,115 & $\begin{array}{c}0,3 \\
48\end{array}$ & $\begin{array}{l}0,7 \\
30\end{array}$ & $\begin{array}{l}1,8 \\
97\end{array}$ & $\begin{array}{l}\text { Tid } \\
\text { ak } \\
\text { Sig } \\
\text { nifi } \\
\text { kan }\end{array}$ \\
\hline $\begin{array}{l}\text { Persepsi } \\
\text { kemanfaata } \\
\mathrm{n}(\mathrm{X} 1)\end{array}$ & 0,850 & $\begin{array}{l}3,0 \\
32\end{array}$ & $\begin{array}{c}0,0 \\
04\end{array}$ & $\begin{array}{l}1,8 \\
97\end{array}$ & $\begin{array}{l}\text { Sig } \\
\text { nifi } \\
\text { kan }\end{array}$ \\
\hline $\mathrm{R}$ & & & 0,596 & & \\
\hline R Square & & & 0,356 & & \\
\hline $\mathrm{F}$ & & & 10,191 & & \\
\hline Sig. & & & 0,000 & & \\
\hline
\end{tabular}

Variabel Terikat: Niat untuk menggunakan (Y), $\alpha$ $=0,05$ 


\subsubsection{Hipotesis Pertama}

Melihat $\mathrm{t}$ tabel dalam pengujian hipotesis pada model regresi, perlu menentukan derajat bebas atau degree of freedom dan hal ini ditentukan dengan rumus : $D f=n-k$, maka 40$3=37$, kemudian dicari nilai $t$ pada $t$ tabel, diketahui nilai $t$ tabelnya adalah sebesar 2,02619 dengan $\alpha=0,05$.

Hasil pengujian terhadap variabel persepsi kemanfaatan diperoleh nilai $t$ sebesar $3,032>2,02619$ nilai $t$ tabelnya, dan nilai sig sebesar $0,004<0,05$, sehingga dapat disimpulkan bahwa variabel persepsi kemanfaatan berpengaruh signifikan terhadap niat untuk menggunakan sistem informasi akademik.

\subsubsection{Hipotesis Kedua}

Melihat $\mathrm{t}$ tabel dalam pengujian hipotesis pada model regresi, perlu menentukan derajat bebas atau degree of freedom dan hal ini ditentukan dengan rumus : $\mathrm{Df}=\mathrm{n}-\mathrm{k}$, maka 40$3=37$, kemudian dicari nilai $t$ pada $t$ tabel, diketahui nilai $t$ tabelnya adalah sebesar 2,02619 dengan $\alpha=0,05$.

Hasil perhitungan terhadap variabel persepsi kemudahan penggunaan diperoleh nilai t sebesar 0,348<2,02619 nilai t tabelnya, dan nilai sig $0,730>0,05$ nilai $\alpha$, sehingga dapat disimpulkan bahwa variabel persepsi kemudahan penggunaan tidak berpengaruh signifikan terhadap niat untuk menggunakan sistem informasi akademik.

\subsubsection{Hipotesis Ketiga}

Melihat $\mathrm{F}$ tabel dalam pengujian hipotesis pada model regresi, perlu menentukan derajat bebas atau degree of freedom (df) atau dikenal dengan df2 dan juga dalam $F$ tabel disimbolkan dengan N2. Hal ini ditentukan dengan rumus:df1 $=\mathrm{k}-1, \mathrm{df} 2=\mathrm{n}-\mathrm{k}$, maka df $1=3-1=2$, dan df2 = $40-3=37$, kemudian dicari nilai $\mathrm{F}$ pada Ftabel, maka diperoleh nilai dari $\mathrm{F}$ tabel sebesar 3,25.

Hasil perhitungan variabel persepsi kemudahan penggunaan dan persepsi kemanfaatan terhadap niat untuk menggunakan diperoleh nilai $F$ sebesar $10,191>3,25$ nilai $F$ tabelnya, dan nilai sig sebesar $0,000<0,05$ nilai $\alpha$, sehingga dapat disimpulkan bahwa variabel persepsi kemudahan penggunaan (X1) dan persepsi kemanfaatan (X2) secara bersamasama (simultan) berpengaruh signifikan terhadap niat untuk menggunakan (Y) sistem informasi akademik.

\subsubsection{Pengujian Hipotesis Keempat}

Hasil perhitungan menyatakan bahwa variabel persepsi kemanfaatan memberi pengaruh dominan dibanding dengan variabel persepsi kemudahan penggunaan terhadap variabel niat untuk menggunakan sistem informasi akademik (SIAKAD) di IKIP Budi Utomo Malang, hal ini dapat buktikan dengan melihat nilai koefisien regresi variabel bebas terhadap variabel terikat. Berdasarkan hasil uji regresi berganda diperoleh nilai koefisien regresi variabel persepsi kemudahan penggunaan sebesar 0,115 dan persepsi kemanfaatan sebesar 0,850 terhadap variabel dependen yaitu niat untuk menggunakan.

\section{KESIMPULAN}

Kesimpulan dari penelitian ini setelah dilakukan penelitian secara menyeluruh adalah variabel persepsi kemudahan penggunaan tidak berpengaruh signifikan secara parsial terhadap variabel niat untuk menggunakan, sedangkan variabel persepsi kemanfaatan berpengaruh signifikan secara parsial terhadap sikap terhadap penggunaan.

Persepsi kemudahan penggunaan dan persepsi kemanfaatan secara simultan memberi pengaruh kepada niat untuk menggunakan sistem informasi akademik untuk mahasiswa dengan kontribusi sebesar $36 \%$.

Persepsi kemanfaatan memberi pengaruh lebih dominan dibanding persepsi kemudahan penggunaan terhadap niat untuk menggunakan sistem informasi akademik untuk mahasiswa di IKIP Budi Utomo Malang.

\section{REFERENSI}

Doleck, T., Bazelais, P., \& Lemay, D. J. (2017). Examining the Antecedents of Facebook Acceptance via Structural Equation Modeling: A Case of CEGEP Students. Knowledge Management \& E-Learning, 9(1), 69-89.

Fatmasari, \& Ariandi, M. (2014). Penerapan Metode Technology Acceptance Model (TAM) terhadap Penerimaan KRS Oonline ( Studi Kasus : Mahasiswa Ilmu Komputer Universitas Bina Darma Palembang ). MATRIK, 16, 1-9.

Fatmawati, E. (2015). Technology Acceptance Model (TAM) untuk Menganalisis Penerimaan terhadap Sistem Informasi Perpustakaan. Iqra', 9(1), 1-13. 
Gokcearslan, S. (2017). Perspectives of Students on Acceptance of Tablets and Selfdirected Learning with Technology. Contemporary Educational Technology, 8(1), 40-55.

Hamari, J., Keronen, L. (2017). Why Do People Play Games? A Meta-Analysis. International Journal of Information Management, 37(3), 125-141.

Maruping, L. M., Bala, H., Venkatesh, V., \& Brown, S. A. (2017). Going Beyond Intention: Integrating Behavioral Expectation Into the Unified Theory of Acceptance and Use of Technology. Journal of the Association for Information Science and Technology, 68(3), 623-637.

Rahayu, F. S., Budiyanto, D., \& Palyama, D. (2017). Analisis Penerimaan E-Learning Menggunakan Technology Acceptance Model (TAM) (Studi Kasus: Universitas Atma Jaya Yogyakarta). Jurnal Terapan
Teknologi Informasi, 1(2), 87-98. https://doi.org/10.21460/jutei.2017.12.2 0

Sayekti, F., \& Putarta, P. (2016). Penerapan Techlonogy Acceptance Model (TAM) dalam Pengujian Model Penerimaan Sistem Informasi Keuangan Daerah. (3), 196-209.

Supriyanti, \& Cholil, M. (2016). Aplikasi Technology Acceptance Model pada Sistem linformasi Manajemen Rumah Sakit di Rumah Sakit Ortopedi Prof. Dr. R. Soeharso Surakarta. Ekonomi Manajemen Sumber Daya, 18(1), 42-51.

Sutedjo, B., \& Oetomo, D. (2006). Perencanaan dan Pembangunan Sistem Informasi Sistem Informasi. Yogyakarta: Andi.

Wiguna, W. (2018). Acceptance Test pada ESAHASS 02300 Menggunakan TAM. IJCIT (Indonesian Journal on Computer and Information Technology), 3(1), 101-109. 